Unity Journal

Vol. III, 220-231, 2022

Doi: https://doi.org/10.3126/unityj.v3i01.43327

Prithvi Narayan Shah Research Center

Directorate General of Military Training, Nepali Army

Kathmandu, Nepal

\title{
Military Diplomacy: Role of Nepali Army in Reshaping Nepalese foreign Policy
}

\author{
Sujan Kafle
}

\begin{abstract}
Development of the concept of foreign policy began with the unification of Nepal which can be reflected through Prithvi Narayan Shah's teaching (Divya Upadesh). Foreign policy is an external display of the nation's internal strengths and aspirations. Foreign policy is an extension of domestic policy. How is the relation maintained with international community? How is our international relation guided? Country's foreign policy is determined on the basis of various principles through diplomatic channels. While in the developing world context, military diplomacy is also one of the tools to determine the foreign policy of Nepal. Military diplomacy is a peaceful use of military in field of diplomacy to achieve the goals of national foreign policy. This research article examines the role of the Nepali Army in shaping up the Nepalese foreign policy tracing its importance's from the historical perceptive. What can be the role of the Nepali Army in strengthening the country's foreign policy? This paper further elucidates history about the military diplomacy of Nepal and also focuses on the role played by the Nepali Army in the UN peace keeping mission making this as one of the parameters for determents of foreign policy of Nepal. Also, military attachés in
\end{abstract}

many of the foreign countries with their vital roles have been able to reshape Nepal's relations with international communities through their strengthened military diplomacy those agents and organizations. This study is methodologically based on the collected information from secondary sources, journal, article, and study of activities of the Nepali Army.

Keywords: Military attaché, Foreign policy, Nepal Army, Military Diplomacy, International Relations, UN Peace Keeping Mission, Peace Zone Proposal

\section{Introduction}

Nepal is a small landlocked country, located between two strong and powerful countries of Asia, China, and India. Yet, a never colonized history of Nepal makes it an interesting terrain to explore. The history of foreign policy development in Nepal is believed to have begun after 1959 (Siwakoti, p. 193). But it is undeniably a validated assumption to stress that the development of the concept of foreign policy has evolved since unification campaign of Prithvi Narayan Shah. This fact is evident in Prithvi Narayan Shah's teaching (Divya Upadesh) which has provided basis for foreign policies and strategies. But then there seems to be open policy sometimes, 
and a policy of pleasing Britain sometimes, without the adherence to a solid foreign policy.

A country determines different kinds of strategy and tactics to establish relationship with other countries and refers it as 'foreign policy'. Hence, Foreign policy is an external display of the national internal strengths and aspirations. It is a wheel that acts as coordinating between states. Mainstream International Relation theory tends to view foreign policy as a practice used to solve problems between countries while critical theory views foreign policy as constitutive of those problems the others take for granted (Johannes Dragsbaek Schmidt, Manish Thapa, 2012).

Foreign policy consists of long-term goals, set by a nation state in its relations with its immediate neighbors, and other international powers that it must deal with in promoting its own national interest (Deutsch, 1968, p. 100). Foreign policy is extension of domestic policy. Nepal has also maintained its own foreign policy which has different objectives.

The fundamental objective of Nepal's foreign policy is - 'to enhance the dignity of the nation by safeguarding sovereignty, territorial integrity, independence, and promoting economic wellbeing and prosperity of Nepal. It is also aimed at contributing to global peace, harmony, and security.'

Diplomacy is the instrument for the implementation of foreign policy. The importance of diplomacy arises from the fact that most foreign policies are stated very generally, without spelling out specific measures for implementation. Diplomacy is the primary political instrument used by states in pursuing foreign policy goals.

\section{Military diplomacy as subset of Defense Diplomacy}

Defense diplomacy is a peaceful application of resources from across the spectrum (range/ variety) of defense, to achieve positive outcomes in the development of a country's bilateral and multilateral relationships. Military Diplomacy is the subset of Defense Diplomacy. Defense diplomacy does not include military operations, but subsumes such other defense activity as international personnel exchanges, ship and aircraft visits, high level engagement, bilateral meetings, training and exercises, regional defense forums, security building measures etc.

Shafikul Alam defines military diplomacy as the peaceful use of military in the realm of diplomacy to achieve the goals of national foreign policy (Shafikul Alam, 2013). He lists many advantages of military diplomacy if properly executed, like enhancing defense relationships, strengthening defense capabilities in areas of defense equipment, major defense purchases, enhancing military capabilities, assistance to friendly foreign countries to develop their defense capabilities and promoting military interoperability.

Military diplomacy is a form of soft power that encompasses the government's efforts in illustrating the fundamental mechanism to render military diplomacy effectively functional in geopolitical complexities (Rawal P. , 2019, p. 3). Military diplomacy is the activity of the Ministry of National Defense in the sphere of security and defense of the state in the international arena (Lech DRAB, 2018, pp. 57-71).

According to Swistek, the tasks under military diplomacy, as an instrument of foreign policy and state security can be enlightened as: - 
- Creating bilateral and multi-lateral contacts of military and civilian defense official of foreign countries; appointing defense attaché in country's foreign missions,

- Preparing

bilateral/multi-lateral security and defense agreements; conducting training activities with foreign military and defense personnel,

- Exchanging experience with foreign military and civilian defense officials including experiences on civil-military relations and democratic control of armed forces'

- Proving military assistance and support to other countries, including aid, materials, and equipment when there is need and request during the disaster or humanitarian crises.

Additionally, the military diplomacy offers various kinds of military advice and military counselling in case of any needs, and it can also play a vital role in arms control and disarmament process.

\section{Thrashing out History of military Diplomacy in Nepal}

Nepal: a landlocked country located in between two powerful countries, validates the narration of Prithvi Narayan shah as being the Yam between two power nations. The pride is bestowed on the fact that Nepal has never been colonized in its entire lifetime. These acclamations are evident in the teachings; Divya Upadesh, of Prithvi Narayan Shah. Since unification campaign of Nepal would be unattainable until the recruitment of strong army, Prithvi Narayan Shah usurped the development of Nepali Army. Along with it, war materials were to be prepared and it was made possible by bringing technicians and experts from abroad. Thus, after the Unification of Kathmandu Valley by Gorkhali troops, Gorkhali armed forces came to be known as the Nepali Army and this can be acclaimed as the beginning of military diplomacy in Nepal.

Prithvi Narayan Shah used military as the hard power to integrate all the scattered smaller states to found Nepal. However, he believed that Nepal should maintain a defensive narrative in regard to its stronger northern and southern neighbors and only go into war if it was unavoidable (Rawal , 2019, p. 15). During the period of 18141816, Nepal fought war with British East India Company which ultimately ended with the Treaty of Sugauli on December 2, 1815, signed by Raj Guru Gajraj Mishra aided by Chandra Sekher Upadhayaya from Nepal and Lieutenant Colonel Paris Bradshaw form British East India Company although it was costly affair for Nepal. The treaty welcomed the establishment of British representative in Kathmandu and allowed Britain to recruit Gurkhas for military services. For Nepal, Anglo-Nepal War led to a realization that it was the end of the expansion era, and for the British it led to a realization that it was difficult to fight with Nepali on their terrain. The British also realized that it would be an uphill task to govern Nepal, and they gave up any notion of bringing Nepal under their empire and formed alliance to use the state as a buffer zone. This alliance, which lasted for more than a hundred years, was due to military diplomacy (Rawal, 2019, p. 17).

After the Rise of Jang Bahadur Rana, power related to administration, justice, foreign relations, and Army was vested on the Ranas absolutely. Jang Bahadur realized that due to lack of strong opposition to counterpoise them, British could attack Nepal at any time. 
To neutralize the danger, he reversed the antiBritish policy adopted by King Rajendra. In an attempt to avoid the fate of other smaller Indian states, overtaken by the British, Jang Bahadur and his successors reoriented the Nepalese foreign policy which gave Nepal a significant role in upcoming events on the plains of India (Rose, 1971). During the Indian Mutiny of 1857-58, Jang Bahadur Rana sent a contingent of Gurkha soldiers to aid the British in Gorakhpur and Lucknow where NA performed well, culminating in the capture of Lucknow. Military Support from Nepal accompanied a lasting impression, and exultant British India reciprocated Nepal by helping it to regain land of terai lost during the Anglo-Nepal War and in the meantime, Nepal convinced the British to respect the sovereignty of Nepal (Rawal P. , 2019, p. 21). The territory that Nepal gained by aligning with the British rather than fighting them was then called 'Naya Muluk' which includes four districts-Bake, Bardia, Kailali and Kanchanpur of presentday Nepal. Also, a treaty between Nepal and the British Government was concluded on $1^{\text {st }}$ November, 1860 , known as Boundary Treaty which states "The British Government hereby bestows on the Maharajah of Nepal in full sovereignty, the whole of the lowlands between the Rivers Kali and Raptee, and the whole of the lowlands lying between the River Rapti and the districts of Goruckpore, which were in the possession of the Nepal State in the year 1815, and were cede to the British Government by Article III of the Treaty concluded at Sugaulee on the 2nd of December in that year." Then, onwards the relationship between British and Nepal continued making military diplomacy, a focal point.
Key Highlights of Foreign Policy, 2077 and National Security Policy 2073 in connection to Diplomacy

To adapt to the changing context, update and bring functional uniformity, ease and coordination, Government of Nepal in 2077 formulated foreign policy integrating and synthesizing various diplomatic practices adopted in the past. Nepal's strategic efforts are focused on making international relations fair, impartial, accountable, and cooperative. To create favorable international conditions through active and effective diplomacy, foreign policy has been reflected to get maximum goodwill support and cooperation from all friendly nations including neighbors. And, to uphold the nation dignity in the international community, Nepal's foreign policy is guided by the following principles:

1) Protection of Nepal's independence, sovereignty, geographical integrity, independence and national interest and enhancement of national honor and dignity,

2) Universal equality,

3) Principle of Panchsheel,

4) The spirit of the United Nations Charter,

5) Non- alignment,

6) Mutual respect and benefits,

7) Recognition of international law and world peace,

8) Peaceful settlement of disputes,

9) International cooperation,

10) Justice, equality, and accountability,

11) Mutual friendship, cooperation, and collaboration,

12) Democracy, human rights, and the rule of law, 
13) Economic prosperity and prosperity,

14) Environmental balance, protection of mankind and protection of the earth.

Working in line of these guiding principles, Nepal Army potentially can play an important role in the implementation of foreign Policy through military diplomacy and even reshaping this for the betterment of the nation. Every state prioritizes security issues in foreign policy. As such, Nepal has also mentioned about this as major issue in framing foreign policy and Nepal Army has been given responsibility to maintain and ensure it. Different other policies are also made under foreign policy like, it has mentioned that contribution is made for the promotion of world peace, human rights, and sustainable development by emphasizing the central role of the United Nations in multilateral diplomacy. For this policy to fulfill Strategy is kept as, to make Nepal's special contribution and role in world peace and security more effective also Increasing the capacity, resources, training, and coordination required to further contribute to the international peace work under the auspices of the United Nation. To achieve this Policy Diplomacy as an instrument is used, moreover issue regarding this military diplomacy can be more effective.

Similarly, National Security Policy is formulated for protection and promotion of national unity, sovereignty, territorial integrity, national unity, independence, and dignity of Nepal and to achieve national objectives and aims by protecting and addressing the changed international, regional, and national security atmosphere, geo-political situation and security threats and potentialities as mentioned in matters of paramount national interests. It also entails for promotion of world peace by contributing to international and regional security, creation of a formidable position that territory of Nepal will in no case be allowed to be used against any friendly country etc. Similarly, this policy prioritizes measures to ensure national security, Professionalization and modernization of security agencies, to enhance partnership for efforts for maintaining world peace. Strategic Objective kept under Security policy to defend land, water and air space of Nepal has make policy as enhancing the strategic capacity of Nepal Army in timely manner so as to deter and face any military threat, For the enhancement of Contribution of Nepal in regional and international security for strengthened security management Policies like as contribution in world peace by taking part in world peace movements through the United Nations Enhancing state capacity for development and making of regional or international policies on peace and security, Increasing cooperation in regional and international peace

This National Security Policy remains as directive policy and should be considered while framing out other policies. Various Institutions and agencies are activated and mobilized for the implementation of the National Security Policy and monitoring it with coordination with each another.

Part 3 of National Security Policy 2073 has mentioned about main Institutional Arrangement and has made clear about the role that is to be played by Nepal Army which can be listed as: -

- Coup up with the challenge in case of serious threats to national security and to defend Nepal's independence, sovereignty and territorial integrity from external infiltration and aggressions and to be ready for defending the border security. 
- Developing military technology and research and to be self-reliant in production of arms and ammunitions, explosives, and other materials to be used by security agencies and to regularly assess the supply and need of Nepal Army and to acquire necessary materials.

- Supervising the projects and strategic structures to be constructed with foreign assistance at sensitive areas or near international borders.

- Assisting in developing military relationships with armies of neighboring countries.

- Maintaining the world peace under the aegis of the United Nations and to assist in the foreign policy of Government of Nepal.

- To made coordinate through the Ministry of Defense the activities and interactions of military importance to be conducted by Defense Attaché of the Embassies of the countries having diplomatic relations with Nepal.

\section{Role of Nepal Army}

The Nepal Army has been working continuously for the protection and promotion of the national interest. It has been playing a significant role in establishing peace not only within the country but also in the international arena and has been helping to uphold the country's prestige and dignity. The Nepal Army has been deploying its staff and observers for international humanitarian work to establish peace in various conflictaffected areas of the world and has been providing security assistance to the helpless local people affected by the conflict even in the most difficult circumstances. The role played by the Nepal Army in establishing peace in various conflict affected countries has been praised internationally.

In constitution of Nepal 2072, provision related to Nepal Army is mentioned under Article 267 which recognizes it as separate institution that is committed to constitution for the safeguard of Independence, Sovereignty, Territorial integrity, and National Unity. Similarly, as mentioned in Article 266, National Security Council makes recommendation to the Government of Nepal, Council of Ministers for the formulation of a policy on overall national interest, security and defense of Nepal, and for the mobilization and control of the Nepal Army where Prime Minister remains as Chairperson and Minister for Defense, Minister for Home, Minister for Foreign Affairs, Minister for Finance, Chief Secretary of Government of Nepal along with Commander-in-Chief of Nepal Army remain as members through which they can play role in determining policy regarding protection of national security and integrity of the country.

National Defense Policy was prepared formally for the first time in Nepal and was approved by National Security Council. Usually, such kind of policy is not made public but in general it is said that the defense policy has been prepared based on the relations with the neighbors, modernization of the army and other issues. Defense policy focuses on advancing relations by emphasizing 3D policy (Diplomacy, Development, Defense) (Adhikari, 2019). When the eyes of the world power start falling on Nepal, we must deal it with adherence to our defense policy. Hence, Nepal army has a huge responsibility to confront such issues through military diplomatic relations. 


\section{Contribution of Nepal Army in UN peacekeeping operation and strengthening Military diplomacy in relation to foreign policy of Nepal}

There are various forms through which military diplomacy is practiced. One of them is Joint Military Exercises, which is generally practiced by Nepal Army. Nepal Army has been engaged in various kinds of regional as well in extra-regional military exercises to combat Counter- terrorism activities, for various humanitarian assistance. The major involvement of Nepal army is evident in UN peace keeping operation which can be taken as one of the influencing determinants for shaping foreign policy of Nepal. The participatory attitude of Nepal Army in UN- Peace keeping mission has also proven the pragmatical commitment of Nepal in promoting world peace through contribution to international and regional security . Similarly, Security policy 2073 has also enlisted its objective to contribute to maintaining the world peace under the aegis of the United Nations and to assist in the foreign policy of Government of Nepal .

Since the membership in UN, Nepal has been an active participant of most of UN peace operations. The participation of the Nepali Army in UN peace support operations spans a period of over a half century covering some 43 UN missions, in which over 1,37,622 personnel have participated. Data provided by Nepal Army on 25th November 2021, states that the Nepali Army has deployed across 12 missions around the world. As a troop contributing country, Nepal ranks second in the world. Currently, Nepali Army has some 5229 soldiers including 223 female soldiers serving in 12 different missions around the globe. Nepal has a commitment to provide up to 10,000 peacekeepers in accordance with request of UN. Nepal's peacekeeping force has inscribed the country's mark to some extent, but it is yet to develop as a potential diplomatic tool in support of national interest.

Prime Minister Bisheswar Prasad Koirala in addressing 15th Session of the UN General Assembly said that the foreign policy of Nepal is wholly inspired by the purposes and principles of UN. Foreign Policy of Nepal is also guided by Principle of UN charter and thus, UN peacekeeping operations carried by Nepal army is a tool for implementing Nepal's foreign policy. The government treats Nepalese peacekeeping participation as the sole prerogative of the Nepal Army (Rawal , 2010, p. 65). Contribution in UN peace keeping operation by Nepal Army supported Nepal's zone of peace proposal by 116 countries, including four permanent members of the UN Security Council and Nepal was also elected as a non-permanent Security Council member in 1969-70 and 1988-89 with overwhelming majorities (Rawal S. S., 2010, p. 72). Hence, it is apparent that there exists interrelation between military diplomacy and Nepal army participating in UN peace keeping force. So, in order to promote and protect national interest of Nation, comprehensive peacekeeping should be formed with connection to public interest which can be done through military diplomacy and can be used as a tool for achieving foreign policy of Nepal and give it a new direction. There is competition among the potential contributors and cuts in the funding. There are about 120 countries competing to participate. On the other hand, US has announced plans to reduce its share of paying for UN peacekeeping missions from 28 percent to 25 percent or about US\$ 2.2 billion annually (Joshi, 2076) So, In this context Nepal's policy to commit up to 
10,000 troops in UN peace keeping mission will become challenging unless supported by national policy and will to implement it. At such instance, military diplomacy can play an important role.

\section{Military Diplomacy through joint Military Exercise and exchange of honorary rank to Chief of Nepal Army by India and vice versa}

One of the contributing factors for strengthening military diplomacy is through joint military exercise with India, China, US, and other countries. Exercise Surya Kiran is one of the combined India- Nepal exercises which began since 2011. This exercise is conducted twice a year and is organized by both countries alternately. Importance in area of relief and rescue, including disaster management is enlightened by this exercise and this also helps to strengthening weapons, equipment, tactics, techniques, and procedures for working in an anti-terrorism. The guiding principles of foreign policy based on mutual friendship, cooperation and collaboration, democracy, human rights and the rule of law, environmental balance, protection of mankind and protection of the earth, helps in Professionalization and modernization of security agencies which is the key objective of security policy. Role of Nepal Army defined by Security policy is to develop military technology and research and to be self-reliant in production of arms and ammunitions, explosives, and other materials to be used by security agencies and to regularly assess the supply and need of Nepal Army and to acquire necessary materials which can be achieved through such kinds of joint military exercise. Indian Military of Defense states that the joint training was undoubtedly, an unprecedented success. This also helps in promoting understanding and inter-operability between the two armies and also cementing ties between both the nations.

Similarly, NepalArmy and People's Liberation Army's started joint military exercise called as 'Sagarmatha Friendship-2'. It is aimed at fighting terrorism. The drill might also focus on disaster managementSimilarly, a joint military training between Nepal Army and U.S. Army named Ex-Teak Nail 22 has also been carried which focuses on disaster rescue and search operations skills related to water and high altitude. Such efforts help in molding a better relationship between two countries.

Similarly, Nepal and India have maintained tradition of granting the honorary rank of a general in the Nepal Army to the chief of the Indian Army and vice-versa since 1950 During Nepal's visit of former Indian army chief Gen. K M Cariappa Even though there aroused some political difficulties between two countries, the two armies remained friendly to each other through the exchange of visits of army chiefs and their interactions did not come to a halt. Recently Nepal Army Chief Gen Prabhu Ram Sharma was conferred with the honorary rank of 'General of the Indian Army' by President Ram Nath KovindSuch practice can help to maintain deep military-to-military relation between two countries. During such ceremony the honorary general pays a courtesy visit to the president, prime minister, and defense minister to discuss bilateral issues, and this can be an opportunity to resolve and address various disputes regarding the border and security of both countries and also identify security interests, defense needs and such.

Important role played by military diplomacy is also evident from the exchange of honorary rank to Chief of Nepal and India in resolving 
undeclared economic blockade imposed by India in 2072. Prime minister of Nepal requested the Indian government and the concerned authorities to end the undeclared blockade and allow the smooth supply of essential goods and to avoid retrogression in the long-established relationship between the Nepal and India, but this attempt failed to lift the Indian economic blockade. In this situation old tradition of granting each other's respective army chief with the honorary rank of Chief of Army Staff proved to be a significant military- diplomatic tool in lifting the Indian blockade. This created an opportunity to hold discussions between two country and convince India to ease the trade and transit concerns which helps to reinforce the Nepal-India friendship

\section{Role of Military Attaché of Nepal in shaping foreign policy}

Military Attaché are the military personal who work in embassy as a representative of his/her country's in regarding the area of defense they are responsible for bilateral military and defense relations. Vienna Convention on Diplomatic Relations 1961 has mentioned about the appointment of defense Attaché in article 7 as state can freely appoint the members of the staff of the mission, in the case of military, naval or air attachés. Thus, Military Attaché are also regarded as one of the members of diplomatic mission through which military diplomacy is practiced. Main role played by Military Attaché is to form policy and advocate for country military and security interests, play the role of a military ambassador, observe the condition in host country and analyze the possible security threats for their country by managing and conducting various military joint exercises, play a role in spearheading emergency response and relief efforts at the time of various crises. Military Attaché can analyze the possible security threat and can become ready to face the challenge in case of serious threats to national security and defend Nepal's independence, sovereignty and territorial integrity from external infiltration and aggressions and be ready for defending the border security, conducting diplomatic missions with a high foreign policy priority, appoints military attaché, who are diplomats in uniform but posted in different diplomatic missions (Ghimire, 2020). Nepal deploys these military attachés in many countries for the effective implementation of its foreign policy regarding the security issue. Government of Nepal has established diplomatic relation with 171 countries as of date June 29, 2021 and has established Embassy in 30 countries in which Military Attaché are sent from army officer as members of diplomatic mission in some of these countries in China, USA, India, Pakistan, and Bangladesh. Moreover, having military attaché in China, UK and USA which are the permanent members of the UN Security Council, will help coordinate Nepal's overall presence and participation at UN peacekeeping missions. This also gives importance for government of Nepal to increase the number of attachés in those countries with can help fulfilling diplomacy interest of Nepal.

\section{Reviving Peace Zone Proposal through Military Diplomacy}

King Birendra put forward the official proposal to declare Nepal as a Zone of Peace on February 25, 1975, The Peace Zone Proposal was aimed at strengthening the sovereignty, independence, national integrity, and development of Nepal.

While addressing foreign dignitaries, King Birendra made statement "As heirs to one 
of the most ancient civilizations in Asia, our natural concern is to preserve our independence- - legacy handed down to us by history. The absence of peace will delay, make more difficult and even deform our development. Just as a world without peace will jeopardize our traditional independence" (Adhikari, 2018, p. 61).

The reason behind this proposal is that Nepal does not intend to take sides in any regional conflict, and establishing Nepal as peace zone would ensure political stability and economic progress. Country along with China, Pakistan, the US, the USSR, France, and the UK stands in favor of this proposal, but India did not endorse it because it saw the concept of Zone of Peace as being contradictory to the 1950 Treaty of Friendship.

King Birendra suggested this proposal as a method to institutionalize peace. Nepal's zone of peace proposal would essentially be non-alignment, non-aggression, peaceful settlement of disputes and peaceful economic and social development for the cause of peace and justice.

Nepal succeeded in ending 10 years long armed conflict by signing the Comprehensive Peace Agreement (CPA) on November 21, 2006, between the then government of Nepal and CPN (Maoist). Through this agreement, political, economic and social change in the country committed with humanitarian law and human rights principles, democracy, peace, prosperity, independence, integrity, sovereignty, and self-respect of the country and also committed for the investigation about seriously violating human rights during the period of conflict create an environment of reconciliations in the society by forming Truth and Reconciliation Commission and which it was established on 10 February 2015 having the objective for sustainable peace and reconciliation by enhancing spirit of mutual good faith and tolerance in the society upon bringing about reconciliation. Provide reparation to the victims in which commission is working thus this can be regarded as basis for establishment of peace in Nepal.

Making this thing as basis achievement for the establishment of peace and resolving the conflict, also by analyzing the role played by Nepal Army in establishment of world peace through participation in UN peace keeping mission. Nepal can again keep forward about peace zone proposal globally for strengthening the sovereignty, independence, national integrity, and development of country. Role of Nepal Army defined by security policy is Contribute to maintaining the world peace under the aegis of the United Nations and to assist in the foreign policy of Government of Nepal which Nepal Army is always committed in this regard. For Reviving Peace zone proposal Military Diplomacy can also play great role to make clear and convince about this thing for other nation. As during the time when King Birendra put forward about this India become hindrance for approval of this proposal, now Nepal has able to maintain good relationship with India through military level even when if their exist political misunderstanding in some condition.

\section{Conclusion}

Through this overall study it is found that unification campaign lead by Prithvi Narayan Shah sowed seeds for the rise of foreign policy and military development . By having proper soil suited foreign policy, any country can promote their national interest. There are various principles to guide and create bases for shaping up foreign policy and to 
assist in the achievement process. Diplomacy has great role in doing so. That is why, it is regarded as primary instrument. There are different forms of diplomacy and among those, military diplomacy plays great role in context of Nepal for achieving foreign policy shaped by the Government of Nepal and also attain new dimension of determining foreign policy regarding the internal security, sovereignty, peace, and integrity of country. Nepal has a long history of practicing military diplomacy which proves the substantial role it has played in shaping up foreign policy of Nepal. Prithvi Narayan Shah viewed Nepal as "yam between two Stones" which can be translated to meaning that our country is located between two power nation India and China. So, he always adopted the policy of maintaining good and equal relationships with China and India and also insisted his successors to do so, during that time of history, foreign policy was thus shaped up centralizing this fact as primary and now in present, it is designed to ensure economic progress and development of country. In present context, the thoughts of yam between two states can be changed as Nepal being the bridge between two economically strong countries. Because Nepal lies in between, it can ensure safety to India and China in matter about security threat for each other as it has promised Nepal has mentioned about that Nepal will not allow to use its territory against any friendly country. Hence, in this regard, military diplomacy can play great role from this Nepal can be benefited from both economically powerful country.

Additionally, roles played by Nepal army in UN peace keeping force for creating peace and security in world is also praiseworthy which can Nepal use as an opportunity to create good relationship with various nations around the globe. Through this mission, various kinds of bilateral agreement can be made from military level for the protection and promotion of national interest. Increasing in role and number of Military Attaché by Nepal can also play important role for the protection of National security of Nepal. Nepal Army being a permanent institution, can frame out various policies for protection of national interest of Nepal and can work on it through military diplomacy. The casual possibility of weak representation of Nepal in international arena caused by unstable political situation, can be assuaged by Nepal Army through its suggestion of permanent and diplomatic foreign policies to government of Nepal. Thus, Nepal Army is concerned institution expected to safeguard sovereignty, territorial integrity, and independence of Nepal.

\section{References}

Adhikari, C. S. (2019, January 2). Defence policy is set along with Security policy. . Annapurna Post. Retrieved December 10, 2021, from https://annapurnapost.com/news/116744

Adhikari, D. R. (2018, July). A Small State between Two Major Powers: Nepal's Foreign Policy Since 1816. Journal of International Affairs, 2, 42-74. doi:https://doi.org/10.3126/ joia.v2i1.22575

Baniya, B. G. (2076). Military Diplomacy: An Important Instrument of Small States' Diplomacy in Enhancing their Security in the Contemporary World. Shipahi, 53, 1-10. Retrieved from https://www.nepalarmy.mil. np/annual

Deutsch, K. W. (1968). The Analysis of International Relations. New Jersey: Prentice Hall Inc.

Ghimire, B. (2021, December 15). Nepal-China military drill in Sept. The Kathmandu Post Retrieved December 3, 2021, from https:// 
kathmandupost.com/valley/2018/07/21/nepalchina-military-drill-in-sept

Ghimire, P. (2020, February). Nepal's military diplomacy: Retrospect and prospect. Unity Journal, 1, 120-125.

Schmidt. J., \& Thapa, M. (2012, April). The Great Himalayan Game: India and China Rivalry in. Contemporary South Asia. Academia.edu. https://www.academia.edu/16461042/The Great_Himalayan_Game_India_and_China_ Rivalry_in_Nepal

Joshi, B. G. (2076). Peacekeeping by Nepal: Toward Diplomacy. Sipahi, 53, 84-91. Retrieved December 8, 2021, from https:// www.nepalarmy.mil.np/fortinity

Lech Drab (2018). Defence DiplomacyAn Important Tool. Security and Defence Quarterly, 57-71. Retrieved December 5, 2021, from https://doi. org/10.5604/01.3001.0012.5152

Poudel, S. S. (2019). Nepali Foreign Policy and Zone of Peace: An Attempt at Neutrality? . NIPORE. Retrieved December 7, 2021, from https://nipore.org/wp-content/uploads/kalinspdf/singles/nrc0015-nepali-foreign-policyand-zone-of-peace-an-attempt-at-neutrality. pdf

Pradhan, S. B. (2010, December 2). Indian Army Chief in Nepal to Receive Top Honours. .Outlook India. Retrieved December 3, 2021, from https:/www.outlookindia.com/ newswire/story/indian-army-chief-in-nepalto-receive-top-honours/705755

Rawal, P. (2019). Military Diplomacy and Its Role in the Foreign Policy of Nepal. Thesis , Naval Postgraduate School Monterey. Retrieved December 5, 2021, from http://hdl.handle. net/10945/64054

Rawal, S. S. (2010). United Nations Peacekeeping Participation and Civil Military Relations in Troop Contributing Countries. Thesis, Naval Postgraduate School, Master of Arts in Security Studies. Monterey, California. Retrieved December 6, 2021, from http://hdl. handle.net/10945/5435

Rose, L. E. (1971). Nepal Strategy for Survival (pp. 105-107). Los Angeles, London: University of California Press.

Shafikul. A. (2013). Military Diplomacy-A Tool to Pursue Foreign Policy. Mirpur Papers.

Siwakoti, G. (n.d.) Introduction to International Relation. Nepal : Ratna Pustak Bhandar.

Swistek, G. (2012). The Nexus Between Public Diplomacy and Military Diplomacy in Foreign Affairs and Defense Policy. Spring, 11, 79-86. Retrieved December 7, 2021, from https://www.jstor.org/stable/26326276 